\title{
On two recently published books on the genus Colias Fabricius, 1807 (Lepidoptera: Pieridae)
}

\section{О двух недавно опубликованных книгах, посвяшенных роду Colias Fabricius, 1807 (Lepidoptera: Pieridae)}

\author{
S.K. Korb ${ }^{1}$, O.G. Gorbunov ${ }^{2}$ \\ С.К. Корб ${ }^{1}$, О.Г. Горбунов
}

\begin{abstract}
${ }^{1}$ Russian Entomological Society, Nizhny Novgorod Division, P.O.Box 97, Nizhny Novgorod 603009 Russia. E-mail: stanislavkorb@list.ru Русское энтомологическое общество, Нижегородское отделение, а/я 97, г. Нижний Новгород 603009 Россия

${ }^{2}$ A.N. Severtsov Institute of Ecology and Evolution, Leninskii Prospekt 33, Moscow 119071 Russia.

Институт проблем экологии и эволюции А.Н. Северцова, Ленинский пр. 33, г. Москва 119071 Россия.
\end{abstract}

KEY WORDS: Lepidoptera, Colias, new books, review.

КЛЮЧЕВЫЕ СЛОВА: чешуекрылые, желтушки, новые книги, обзор.

ABSTRACT. In the present work some nomenclatorial, taxonomic and zoogeographic errors, which were made in recently published revisions of the genus $\mathrm{Co}$ lias Fabricius, 1807, are examined and corrected. The following nomenclatorial acts are applied: C. alta worthyi Zhdanko, 2012, stat.n., C. phicomone oberthueri Verity, 1909, stat.rest., C. palaeno aias Fruhstorfer, 1903, stat.rev., C. alpherakii roschana Grum-Grshimailo, 1893, stat.rest., C. hyperborea hyperborea Grum-Grshimailo, $1899=C$. hyperborea puella Churkin et Grieshuber, 2001, syn.n., C. regia svetlanae Korb et Yakovlev, 1998, stat. rest.

РЕЗЮМЕ. В настоящей работе изучаются и исправляются некоторые номенклатурные, таксономические и зоогеографические ошибки, сделанные в недавно опубликованных ревизиях рода Colias Fabricius, 1807. Предлагаются следующие номенклатурные акты: C. alta worthyi Zhdanko, 2012, stat.n., C. phicomone oberthueri Verity, 1909, stat.rest., C. palaeno aias Fruhstorfer, 1903, stat.rev., C. alpherakii roschana Grum-Grshimailo, 1893, stat.rest., C. hyperborea hyperborea Grum-Grshimailo, $1899=C$. hyperborea puella Churkin et Grieshuber, 2001, syn.n., C. regia svetlanae Korb et Yakovlev, 1998, stat. rest.

In 2012 and 2014 two books were published dedicated to the genus Colias Fabricius, 1807 in the Old World [Grieshuber et al., 2012; Grieshuber, 2014]. Both works are notable with the pedantic German approach, good knowledge of the subject and ... rather poor grounding in general biology. No analysis of the genitalia besides that already published by someone else; not even hints about an attempt to build a natural systematic order (moreover, in the 2012 book the "Systematic list of the genus Colias" is alphabetical); molecular data are not applied absolutely (although there is much available open access published data, etc.). The authors are basing practically all of their conclusions on wing pattern, while making constant reservations about its variability; in $99 \%$ of cases this serves them as the basis for the synonymizations. The paradox is obvious: the least reliable diagnostic characters for a species are applied, and then these same characters are used for the synonymizations.

The authors obviously make a mockery of some aspects of nomenclature, giving lesser attention to others of no lesser importance. This relates mainly to type localities and nomenclatorial types: in an attempt to clarify a type locality with maximum details (often with the geographical precision to seconds) the authors rather rarely designate nomenclatorial types. Indisputably, the exact knowledge of a place of collection of the nomenclatorial type is useful and the value of such knowledge is great, however most of the sulfurs are strong flyers and can migrate large distances. This makes unlikely the formation of a local subspecies, and in turn, makes senseless an absolutely exact knowledge of a locality where a nomenclatorial type was collected.

The first book [Grieshuber et al., 2012] is written as nomenclatorial and taxonomic revision with strong historical aspect; the second one [Grieshuber, 2014] is, as its author states, a brief review of the genus and serves in general for collections reorganization: "The present Guide, ... . permits a quick overview about this genus and to re-organize a collection". In the first book there is not a single illustration of genitalia. In the second one, there are three illustrations, and none is original. There are no illustrations of the female genitalia at all. Maps of the distribution areas of all the species lack excluded regions, thus often making distributions unreliably wide. It would be logical to place on the maps the localities known to the authors (as dots), as it is done in the overwhelming majority of modern scientific works, however the authors have decided not do this. It is not realistic for us to address the accuracy of all of the maps. 
We shall elaborate below some examples of the incorrect indications of distribution areas.

The most obvious remarks (by far not all) on selected Palaearctic species:

C. hyale (Linnaeus, 1758). For this species, two subspecies are cited (the nomenotypical one and palidis Fruhstorfer, 1910) with the separation in Altai. The distribution of $C$. hyale is shown as uninterrupted from the Atlantic to Pacific coast. However, in the deserts and semi-deserts of Central and Southern Kazakhstan this species doesn't occur. It is assumed that these desert areas provide natural borders between the european, south-siberian and tian-shanian populations of the species. Additionally, this species doesn't occur in the considerable region of the trans-uralian steppes (q.v., e.g. Lukhtanov, Lukhtanov, 1994: 64, map). Therefore, synonymization of the taxon grieshuberi Korb, 2004 with the nomenotypical subspecies is seen by us as erroneous, while distribution of the nomenotypical subspecies in the East is limited by the Ural Mts. Beyond the Urals, behind the wide belt of the trans-uralian steppes, begins the distribution area of another subspecies: palidis (hence the border comes not in the Altai as J. Grieshuber demonstrates, but along the Ural). The distribution area of grieshuberi is separated from palidis by the wide areas of the deserts of South-East Kazakhstan (Sary-Taukums, Kyzyl-Kums etc.). The taxonomic arrangement of $C$. hyale is thus: $C$. hyale hyale (Linnaeus, 1758); C. hyale palidis Fruhstorfer, 1910; $C$. hyale grieshuberi Korb, 2004.

C. alta Staudinger, 1886. We agree with the synonymization of $C$. alta $=C$. worthyi Zhdanko, 2011, however the latter taxon undoubtedly is a good subspecies. The area of distribution of worthyi is situated in Interior Tian-Shan (the Baydulu, Naryn-Too and MoldoToo mountains ranges), the distribution of alta includes Pamir-Alai and the eastern part of Gissar-Darvaz. Thus between the areas of alta and worthyi the vast regions of Interior Tian-Shan are situated, and the natural border between these two taxa is the Kara-Darya river and the Fergansky mountain range. Because of their wide geographic separation, it is incorrect that both populations represent a single subspecies. The taxonomic scheme of the species: C. alta alta Staudinger, 1886; C. alta worthyi Zhdanko, 2012, stat.n.

C. alfacariensis Ribbe, 1905. The taxon sareptensis, established as an aberration by $\mathrm{O}$. Staudinger and subsequently raised in rank to a variation by S. Alpheraky, is treated by the authors of both books as a taxon, described by S. Alpheraky separately from O. Staudinger's description. On this basis, the authors designated the lectotype of sareptensis Alphéraky, 1875 from the vicinity Taganrog, and deposited currently in Zoological Institute, Russian Academy of Sciences, Saint-Petersburg (ZIN). However, S. Alpheraky doesn't describe new taxon in his work, but positively elevates the rank O. Staudinger's name: "one of which, however, should be considered as a permanent modification, varietas [variety] and not as an aberration as Dr. Staudinger supposes, naming it ab. Sareptensis" [Alpheraky, 1875: 153; translated from Russian]. According to ICZN Art. 46.2, when lowering or raising the status of a speciesgroup taxon, its type material remains unchanged with the same type specimen (specimens) for which the taxon was first established regardless of the materials initial status (q.v. Arts. 72.1.1, 73.2 and 74.1). Hence the lectotype designation of sareptensis by the authors of the books being reviewed is not valid. We resolved this problem by fixing a valid lectotype for sareptensis in the O. Staudinger's type series, however this fact is ignored in the books reviewed. It should be noted also, that we see as incorrect the total synonymization of all the subspecies within alfacariensis: differences between irano-turkish and european macropopulations are rather considerable (lighter coloration, thinner (partially reduced) elements of the wing pattern); existing natural obstacles make impossible a regular process of gene exchange (Caucasus Mts. and Black Sea basin), but this question requires further investigations.

C. poliographus Motshulsky, 1860. Synonymization of the island subspecies is questionable because of prolonged isolation without contact with the mainland subspecies. Quite strange is the fact that J. Grieshhuber [2014] did not illustrate males of the island subspecies; all of the males illustrated in the book are from the mainland; the only illustration presented of island butterflies is a female from Tanigumi (Japan). The status of the mainland subspecies (naukratis Fruhstorfer, 1910, manchurica Kishida, 1935, amdensis Bollow, 1930) need additional clarification; here we provisionally accept that the single subspecies naukratis (this is the senior available name) occurs over all of the mainland area, while the islands are inhabited by the nomenotypical subspecies (but that clarification is needed for the taxa formosana Shirôzu, 1955, tokotana Bryk, 1942 and tomarias Bryk, 1942, which described from the different islands of Japan archipelago).

C. phicomone (Esper, 1780). Synonymization of all the known subspecies to the nomenotypical one appears unconvincing. The area of distribution of the species is disjunctive-montane: Central and Southern Alps (first disjunction) and Pyrenees (second disjunction) (see, for example: Kudrna et al., 2011: 141, map). The author mentions a large variability of the species (which is characteristic for all the genus Colias, that would be sufficient to mention once in the introduction). Pyrenean butterflies in general are darker than the Alpine ones and deserve separation into their own subspecies; the senior available name for this action is $C$. phicomone oberthueri Verity, 1909, stat.rest.

C. tyche (Böber, 1812). A picture quite opposite to that described above: with the continuous area of distribution on the mainland being separated into subspecies (we will not dispute the accuracy of the separation of the island populations as subspecies). It is curious to learn about the authors' suggested areas of distribution of some of the subspecies: a nomenotypical subspecies flies in Siberia, with its type locality including "... 
somewhere along the Lena River from its source to its mouth" [Grieshuber, 2014: 21], and subspecies kolosovae Churkin, Grieshuber, Bogdanov and Zamolodchikov, 2001 - ...also in Siberia (stated: "Kamchatka, Chukotka, Taimyr"). Obviously according to the data of the authors, the nomenotypical subspecies occurs between the taymyrian and chukotkan populations of the subspecies kolosovae. Meanwhile the taxa kolosovae and tyche were synonymized previously in 2011 [Korb, Bolshakov, 2011].

C. palaeno (Linnaeus, 1761) and C. palaeno aias Fruhstorfer, 1903. J. Grieshuber had separated the taxa palaeno and aias, giving full species status to the latter one (of islands), providing this elevation of a status with a short comment: "Taxon aias has been generally associated with C. palaeno, but due to its distinct phenotype, it is best considered to be specifically distinct". Mentioned differences (more wide marginal border etc.), however, look quite unconvincing on the basis of the statement on the preceding page, virtually indistinguishable in the main details from aias, taxon sugitanii Esaki, 1929 is illustrated, which in its turn is quite similar to the taxon orientalis Staudinger, 1892. Besides, the type locality of aias (Asama-yama volcano in the eastern part of Nagano province) is situated approximately 80 $\mathrm{km}$ to the east from the type locality of sugitanii (Yonen and Tsubakuro mountains in the western part of Nagano province). As a whole for C. palaeno, a clinal variability of the width of a black marginal border is typical from west to east: in the eastern populations this border is wider and of more saturated black color (see, for example, Verhulst, 2000: pl. 19). Japanese taxa represent the extreme phenotypes of the cline and could not be considered in status higher than subspecies: $C$. palaeno aias Fruhstorfer, 1903, stat.rev. We should note also that for C. palaeno J. Grieshuber lists numerous subspecies in the East-Palaearctic portion of the distribution (4 subspecies against 2 in West Palaearctic). It appears to us that all the East-Palaearctic subspecies, excluding island populations, are the synonyms of the single subspecies orientalis: to suppose that $C$. palaeno inhabits this territory with large interpopulational gaps is incorrect, since the larval food plant (bog bilberry, Vaccinium uliginosum) grows everywhere here.

C. alpherakii Staudinger, 1882. All the subspecies of this polymorphic species are downgraded into synonyms of the nomenotypical subspecies, except the afghan kohibaba Wyatt et Omoto, 1966. Meanwhile the distribution region of $C$. alpherakyi in Central Asia is not uninterrupted, the pamirian part of area is separated from the alaian one by the wide Alai valley and broad glaciations of the Transalai mountain range, and from Gissar - with the broad glaciers of Central Pamir. Thus the distribution area of this species is separated at least into three large metapopulations, having narrow contact zones in some mountain ranges, however insufficient for the mixing of the phenotypes. On this basis the subspecies structure of the species should be considered as such: pamirian-badakhshanian subspecies C. alpher- akii roschana Grum-Grshimailo, 1893, stat.rest., badakhshanian subspecies C. alpherakii kohibaba and alaian nomenotypical subspecies.

C. tamerlana Staudinger, 1897 and C. mongola Alphéraky, 1897. The name mongola objectively has publication date priority over tamerlana, stated in the publication itself with sufficient completeness to resolve this question. J. Grieshuber refers to the fact that O. Staudinger had stated in his catalogue [Staudinger, Rebel, 1901] the date of publication for mongola "fin. 1897 " and that S. Alpheraky and O. Staudinger were friends, thus for $\mathrm{O}$. Staudinger it made no sense to synonymize the name by S. Alpheraky - but at the time of publication of the catalogue of 1901 O. Staudinger was already dead more than half-year, so the catalogue was not completed by him; additionally, as the basis for the J. Grieshuber's conclusions were based on the dates of receiving volume $9^{\text {th }}$ of Romanov's Memoirs by the Library of Harvard (18.12.1897) and of the presentation of this volume at the meeting of the French Entomological Society 10.11 .1897 (i.e. more than a month before the volume was received at Harvard). According to article 21.2 of the Code, if the date is stated it is accepted as correct, unless proven otherwise. There are no reasons to consider that the date indicated at the Contents page of the $9^{\text {th }}$ volume of the Memoirs is not the date of its publication. The fact that the given volume was received at different times by various scientific institutions in Europe and America, and also by O. Staudinger, merely indicates that the volume's delivery took place quite unevenly to different places on Earth at the end of the century before last. The main argument in favor of the publication of the volume exactly in June 1897 is the fact that the Contents (in which the actual date of printing is stated) could be produced and bound with the text only after the book had been printed, since computer means of bread boarding were non-existant at that time. Thus the date of the publication of the $9^{\text {th }}$ Volume is definitely fixed in the publication itself, and no attempt is necessary to use incorrect data as a date of publication (date of receiving individual copies of the book), and is entirely contradictory to the Code (usage of article 21.7 unqualified: "If the date of publication is not specified in a work, the earliest day on which the work, or a part of it, is demonstrated to be in existence as a published work", as the article 21.2 is used).

The fixation of the type locality of the taxon mongo$l a$ is proposed by J. Grieshuber "provisionally and without evidence" which causes serious concern: how it is possible to postulate a nomenclatorial act of the correction of the type locality without proof and provisionally? In the case of mongola the basis for J. Grieshuber's rejection of O. Gorbunov's conclusions, which are based on the travel notes and diaries of the collector of the type series of mongola, is a supposition about this "experienced collector" could not have "confused the yellow C. palaeno with the dark green C. mongola". We shall state the arguments of O. Gorbunov [2012: 673] as a whole: "In the beginning of August I have returned to 
Turan. ... With Rhopalocera was flying a new generation of Calias [sic!], much more numerous than the spring one, of all other species of insects were found only pitiful remains" [Leder, 1893: 33-34]. In the German version of a paper we can see: "Anfangs August nach Turan zurückgekehrt, ... Von Rhopaloceren flog Colias Palaeno in zweiter Generation ..." [Leder, 1894: 227]. But we know that C. palaeno has only one generation that usually flies from mid-June till the end of July, and if Leder collected specifically this species then it would be found indeed in the form of "pitiful remains". However, the type series contains fresh enough specimens, as is seen from the published photographs of the lectotype and paralectotype [Grieshuber, Churkin 2003: pl. 16, figs 5, 6]. Hence we have the right to make an unequivocal conclusion that the type locality of the nomenotypical taxon Colias nastes mongola Alpheraky, 1897 is in the vicinity of the settlement Turan, of Tunkinsky District of Republic Buriatia, Russian Federation with the approximate geographical coordinates $51^{\circ} 38^{\prime} \mathrm{N}$ lat., $101^{\circ} 39^{\prime} \mathrm{E}$ long. These conclusions are supported by the facts published by the collector of the type series himself.

S. Korb [2012] has pointed out that all the taxa of this group (including mongola and tamerlana) refer to the single polymorphic species $C$. cocandica Erschoff, 1874.

C. berylla Fawcett, 1904. The borders between the subspecies are outlined rather strangely: along the parallels. It would have been more logical to define the areas of the distribution along the mountain ranges, where this species occurs.

C. ladakensis C. et R. Felder, 1865. With such a continuous area of distribution (Himalaya) it looks quite strange that the taxon is not separated into any subspecies (which has been done for a number of other species having similar distribution, where at least two subspecies are separated). The distribution of this species is definitely divided into two isolated parts in the central part of a mountain system (some authors divided its area even into three separated parts [Verhulst, 2000: 411]).

C. chrysotheme (Esper, 1781). Three subspecies are cited for this species: the plains european-westsiberian nomenotypical subspecies and two mountain southsiberian subspecies - C. chrysotheme audre Hemming, 1933 (to the east of lake Baikal) and C. chrysotheme elena Gorbunov, 1995 (to the west of the same lake). Differences between audre and elena have not clear separation and exhibit a clinal nature, thus it would be more logical to speak of plains european-westsiberian and mountain southsiberian subspecies; this question requires further investigations.

C. aquilonaris Grum-Grshimailo, 1899 and C. viluensis Ménétriès, 1859. The status of these taxa is interpreted as a subspecies of $C$. hecla Lefèbvre, 1836. This is quite strange, as with the number of subspecies that are cited for hecla (6 subspecies are cited for the Palaearctic; two of these subspecies are described by J. Grieshuber himself). Note that earlier the author of the book considered as separate species some of the taxa enumerated as subspecies (C. aquilonaris, $C$. sulitelma Aurivillius, 1890: q.v. [Grieshuber et al., 2001]). Note the fact that taxonomic conclusions are made without drawings of the genital structures. In the case of "subspecies" whose borders are definitely intergrading, to rely on the wing pattern only is extremely naïve. It has been repeatedly demonstrated for many groups of Lepidoptera that wing pattern characters are quite unreliable for differentiation of similar species in the genera considered as very variable, like Colias (the most recent example-similar species of the genus Melitaea [Jugovic, Koren, 2014]).

C. hyperborea Grum-Grshimailo, 1899. Noting the definitely continuous distribution of this species covering entirely weakly differentiated tundra areas of NorthEastern Siberia, two subspecies are "retained": the nomenotypical subspecies and $C$. hyperborea puella Churkin et Grieshuber, 2001. Meanwhile between these phenotypes there exists and wide range of transitions; such (clinal) variability doesn't allow us to recognize the validity of the subspecies puella: $C$. hyperborea hyperborea Grum-Grshimailo, $1899=C$. hyperborea puella Churkin et Grieshuber, 2001, syn.n.

C. wiskotti Staudinger, 1882. In contrast to the virtually total merging of subspecies for the overwhelming majority of sulfur species, 9 are listed for $C$. wiskotti. This species is probably one of the most variable in the genus, with analysis of material in series demonstrating clear clinal variability in the width and saturation of the black marginal border, discal spots and other characters of the wing pattern (over 1000 specimens in various collections have been examined). Perhaps it is possible to speak with certainty about the subspecific status only of the populations having well defined natural barriers: west-tianshanian C. wiskotti draconis Grum-Grshimailo, 1891 (separated by the vast spaces of Interior TianShan and Fergana Valley), pamiro-alaian nomenotypical subspecies (separated from the more southern populations by the high Transalai mountain range and Alai Valley), pamirian C. wiskotti chrysoptera Grum-Grshimailo, 1888 and afghan-iranian C. wiskotti sweadneri Clench et Shoumatoff, 1956 (separated by the vast intermontane valleys of Badakhshan and Iranian Upland). It is important to note that the author of the book cites two subspecies from the Kirgizsky mountain range: C. wiskotti rueckbeili O. Bang-Haas, 1927 and C. wiskotti separata Grum-Grshimailo, 1888. We, with more than 20 years of exploration of the stated mountain range, never collected $C$. wiskotti there; all the specimens known from the stated mountains were collected more than century ago and most probably are mislabeled.

C. erschoffi Alphéraky, 1881 and C. romanovi GrumGrshimailo, 1885. The author supposes that these species are very close to each other and admits to the probability that they could be merely subspecies of the same species. However, it is absolutely impossible to confuse them; we shall cite the most significant differences in male genitalia: in $C$. romanovi the saccus is 
small and rounded (in C. erschoffi it is massive, angled), with a small and weakly sclerotized pseudouncus (in $C$. erschoffi it is probably half of the uncus in length, strongly sclerotized), rounded tip of valva (in $C$. erschoffi it is sharpened in the shape of a beak).

C. regia Grum-Grshimailo, 1887. Taxon C. regia svetlanae Korb et Yakovlev, 1998, stat.rest. was downgraded to synonymy with the nomenotypical subspecies. The distribution area is shown as continuous for Kyrgyzstan. Meanwhile in the Pamir-Alai part of the distribution, the species occurs more or less widely, while in the Interior and Central Tian-Shan - locally. Central-tianshanian population ( $C$. regia svetlanae) is securely separated from the rest of the distribution area by the high-mountain syrts of Interior Tian-Shan and vast areas of glaciation, therefore its synonymization with the nomenotypical subspecies appears strange.

C. heos (Herbst, 1792). According to J. Grieshuber, in the entire territory of its vast distribution area (approximately a quarter of a Palaearctic territory) the species is represented by the nomenotypical subspecies. It is logical to conclude that is not so: separate phenotypes were described (C. heos kenteana Rühl, 1895, $C$. heos sibirica Lederer, 1852, C. heos decolorata Staudinger, 1897). They differ sufficiently in wing pattern and coloration, and also - no less important occupy isolated mountain regions: Altai-Sayan mountains, Cisbaikal and Transbaikal (including Greater Khingan), where the Altai-Sayan mountain region and Cisbaikal are separated by the Yenisey river valley and vast Ubsu-Noor hollow; Cisbaikal and Transbaikal are separated by lake Baikal and the vast river Selenga basin. Populations inhabiting the stated mountain regions should be definitely separated into individual subspecies.

On the whole, the books on the genus Colias authored by J. Grieshuber might be used as a source of reference information, however nomenclatorial and taxonomic interpretations therein demand a critical revision on the basis of modern biology.

\section{ACKNOLEDGEMENTS}

The authors would like to express their sincere gratitude to the following persons: Mr. Alexei G. Belik (Saratov, Russia) for the translation of the original manuscript into English, and to Dr. Clifford D. Ferris (Laramie, Wyoming, USA) for the stylistic correction of the translation. We also thank Dr. S.Yu. Sinev and Dr. A.L. Lvovsky (Institute of Zoology, St.-Petersburg, Russia), Dr. A.V. Sviridov (Zoological Museum, Mos- cow State University, Moscow, Russia), Dr. W. Mey (Museum für Naturkunde, Berlin, Germany), Dr. J. Kullberg and Dr. L. Kaila (Finnish Natural History Museum, Helsinki, Finland), Dr. B. Huertas (Natural History Museum, London, United Kingdom) for granting access to curated collections.

\section{References}

Alpheraky S. 1875. [Lepidopterans (Lepidoptera) of the vicinities of Taganrog]// Trudy Russkogo Entomol. obshchestva. T.8. P.150226 [in Russian].

Gorbunov O.G. 2012. [On the nomenclature of Colias nastes mongola Alphéraky 1897 and Colias tamerlana Staudinger 1897 (Lepidoptera, Pieridae)] // Zool. Zhurn. Vol.91. P.669-674 [in Russian].

Grieshuber J. 2014. Guide to the butterflies of the Palaearctic region. Pieridae part II. Subfamily Coliadinae. Trine Coliadini. Milano: Omnes Artes. 86 pp.

Grieshuber J., Churkin S. 2003. The lectotypes of Colias diva GrumGrshimailo, 1891, Colias wanda Grum-Grshimailo, 1907, Colias grumi Alpheraky, 1897, Colias cocandica maja GrumGrshimailo, 1891, Colias cocandica tatarica Bang-Haas, 1915, and Colias tamerlana mongola Alpheraky, 1897 (Lepidoptera: Pieridae) // Helios. Vol.4. P.244-271.

Grieshuber J., Lukhtanov V.A., Lvovsky A.L. 2001. Die Lectotypen von Colias hyperborea Grum-Grshimailo, 1900, Colias aquilonaris Grum-Grshimailo, 1900, und Colias hecla var. orientalis Grum-Grshimailo, 1900 (Lepidoptera: Pieridae) // Entomologische Zeitschrift. Bd.111. H.6. S.168-172.

Grieshuber J., Worthy B., Lamas G. 2012. The genus Colias Fabricius, 1807. Jan Haugum's annotated catalogue of the Old World Colias (Lepidoptera, Pieridae), Pardubice-Bad Griesbach-Caretham-Lima: Tshikolovets Publications. 438 pp.

Jugovic J., Koren T. 2014. Wing pattern morphology of three closely related Melitaea (Lepidoptera, Nymphalidae) species reveals highly inaccurate external morphology-based species identification // Nota lepid. Vol.37. No.1. P.75-90.

Korb S.K. 2012. [Butterflies (Lepidoptera: Papilionoformes) of Northern Tian-Shan. Part 1. Families Hesperiidae, Papilionidae, Pieridae, Libytheidae, Satyridae] // Eversmannia. Suppl.3. P.184 [in Russian].

Kudrna O., Harpke A., Lux K., Pennerstorfer J., Schweiger O., Settele J., Wiemers M. 2011. Distribution atlas of butterflies in Europe. Halle: Gesellschaft für Schmetterlingsschutz e.V. 576 pp.

Leder G. 1893. [Brief essay of the entomological excursion into the region of East Sayan] // Izv. Vostochno-Sibirsk. otdela Imperat. Russkogo geogr. ob-va. Vol.24. No.1. P. 3-35 [in Russian].

Leder H. 1894. Entomologische Streifzüge in Sibirien // Wien. Ent. Z. Bd.13. H.7. S.213-227.

Lukhtanov V.A., Lukhtanov A.G. 1994. Die Tagfalter Nordwestasiens (Lepidoptera: Diurna) // Herbipoliana. Bd.3. S.1-440.

Staudinger O., Rebel H. 1901. Catalog der Lepidopteren des Palaearctischen Faunengebietes. Edn. 3. 1 Famil. Papilionidae-Hepialidae. Berlin: Friedländer \& Sohn. 411 S.

Verhulst J. 2000. Les Colias du Globe. Keltern: Goecke et Evers. 500 pp. [in 2 vols.] 